\title{
Konaklama İşletmelerinde Yeşil Pazarlama Uygulamaları: Doğa Residence Otel Örneği
}

\author{
Öğr. Gör. Ayşe Nevin SERT \\ Selçuk Üniversitesi, Beyşehir Ali Akkanat Meslek Yüksekokulu, e-posta: \\ nevinsert@gmail.com
}

\section{Öz}

Dünyadaki çevresel bozulma her geçen gün artmaktadır. Buna bağlı olarak çevresel sorunların etkisini en aza indirmek amacıyla çevre dostu uygulamalara olan eğilim artmaktadır. Turizm sektöründe çevre çok önemli bir faktör olduğundan çevre dostu uygulamaların önemi büyüktür. $\mathrm{Bu}$ uygulamalardan biri de "Yeşil Pazarlama"dır. Bu çalışmanın amacı, konaklama

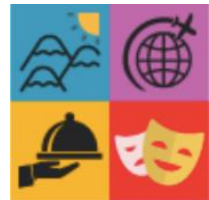

Türk Turizm Araştırmaları Dergisi Cilt. 1, Sayı.1, 2017 ss.1-20.

DOI: $10.26677 /$ tutad.2017.0 işletmelerinde yeşil pazarlama uygulamalarını Doğa Residence otel örneğinde incelemek ve bu uygulamaların işletmelere sağladığı yararları ortaya koymaktadır. Bu amaç doğrultusunda oluşturulan soru formu Doğa Residence Oteli yöneticilerine uygulanmış ayrıca gözlem ve belgelerden yararlanılmıştır. Elde edilen veriler doğrultusunda yeşil pazarlama uygulamalarının uzun vadede işletmelerin maliyetlerini düşürerek karlılığını artırdığ 1 ve itibar kazandırdığı ortaya konmuştur. Ayrıca, işletmelerin tüketici isteklerinin ve duyarlılıklarının değişmesi sonucu bu isteklere cevap vermek için yeşil uygulamalara yöneldikleri de görülmüştür.

Anahtar Kelimeler: Yeşil Pazarlama, Konaklama İşletmeleri, Doğa Residence Otel

\section{Önerilen Atıf:}

Sert, A. N., (2017). Konaklama İşletmelerinde Yeşil Pazarlama Uygulamaları: Doğa Residence Otel Örneği, Türk Turizm Araştırmaları Dergisi, 1(1):1-20. 


\title{
Green Marketing Practices in Hotels: A Case Study of Doğa Residence Otel
}

Lecturer Ayşe Nevin SERT

Selçuk University, Beyşehir Ali Akkanat Vocational School, e-mail: nevinsert@gmail.com

\begin{abstract}
Environmental degradation in the world is increasing day by day. As a result, there is an increasing tendency for environmentally friendly practices to minimize the impact of environmental problems. As the environment is a crucial factor in in the tourism sector environment friendly applications are great importance. One of these applications is "Green Marketing". The aim of this study is to examine the green marketing practices in the hospitality companies in the case of Doğa Residence hotels and to present the benefits that these applications provide. Green marketing applications of Doğa Residence Hotels have been analysed as a case. The questionnaire formulated for this purpose was applied to the managers of Doğa Residence Hotel and the observations and documents were utilized. In the direction of the obtained data, it has been seen that green practices have reduced the expenses of the hotel enterprises and help them to gain reputation. It has also been observed that due to the change in consumer demands and sensitivities, hotel enterprises are turning to green applications to respond to this demand.
\end{abstract}

Keywords: Green Marketing, Lodging Enterprises, Doğa Residence Hotel.

\section{Suggested Ctitation:}

Sert, A. N., (2017). Green Marketing Practıces in Hotels: A Case Study of Doğa Residence Otel, Journal of Turkish Tourism Reseacrh, 1(1):1-20. 


\section{GíRiş}

Günümüzde, dünyadaki çevresel bozulmanın, sanayileşme ve ekonomik küreselleşmenin bir sonucu olduğu açıktır. Hava ve su kirliliği, tarım alanları için yok edilen ormanlar, sera gazları, katı atık gibi sorunlar ve bunların sosyal-ekonomik etkileri tüm dünyadaki teknolojik gelişmeler ve pazar büyümesinin sonucudur. Bu problemler, geçmişte gerçekleşmesinden korkulan problemler iken şimdi insanların günlük hayatını etkileyen problemlere dönüşmüş ve insanların çevreyle ilgili endişeleri artmıştır (Giraldo ve Castro, 2014). İnsanlar doğal çevreyle ilgili endişe duydukça, işletmeler de bu endişelere cevap verebilmek için davranışlarını değiştirmeye başlamışlardır (Uydacı, 2011:54). Buna bağlı olarak, ekonomik büyüme ve çevresel sürdürülebilirlik arasında uygun bir denge sağlayabilmek amacıyla farklı yaklaşımlar uygulanmaya çalışılmaktadır (Giraldo ve Castro, 2014).

Farklı yaklaşım arayışı pazarlama için de geçerlidir. Çevresel sorunlar ve pazarlama, birbiriyle karşıt bir işleyişe sahip olabilir. Biri daha az tüketimi; diğeri ise sistemsel olarak daha çok tüketilmesini amaçlar. Ancak, bu iki olgu her zaman ve zorunlu olarak birbirine karşıt değildir. Pazarlama, yeşil sorunlara karşı duyarlılığı arttırma ya da başka bir deyişle yeni yaşam tarzı fikirlerini 'satma' konusunda yardımcı olmaktadır (Grant, 2008). Bu noktada tüm sektörler için yeşil pazarlama kavramı ortaya çımaktadır. Yeşil pazarlama işletmelere maliyetlerin düşmesi, itibar yükselmesi ve çalışan motivasyonun artması gibi faydalar sağlamaktadır (Kotler, 2014).

Çevre, turizm endüstrisinde en önemli unsurların başında gelmektedir. Bu nedenle turizm işletmelerinin çevreye duyarsız kalması beklenemez. Varlıklarını çevrenin ve buna bağlı olarak turistik talebin sürdürülebilirliğine borçlu olan turizm işletmelerinin yeşil pazarlama uygulamalarına karşı duyarlı olması kaçınılmazdır. Günümüzde turizm işletmelerinin yeşil pazarlama uygulamalarına ilgilerinin arttı̆̆ söylenebilir (Atay ve Dilek, 2013). Bu ilginin nedenlerinden bazıları; turizme konu olan kaynakların korunması, işletmeye sağladığı tasarruf ve pazarlamada önemli bir araç olmasıdır. Bu doğrultuda çalışmanın amacı, çevre dostu yönetimin önemini vurgulamak ve örnek olay yöntemiyle incelenen otelin, turizmin olumsuz etkilerini azaltan ve işletmeye kar sağlayan yeşil otelcilik uygulamalarına yönelik durumunu ortaya koymaktadir.

Buradan yola çıkarak, çalışmanın amacı, çevre dostu yönetimin otel işletmeleri için önemini ortaya koyarak; otelin yeşil otelcilik uygulamalarını örnek olay yöntemiyle bir otel işletmesinde incelemektir. Çevre sorunlarının giderek arttığı bu çağda yeşil uygulamalar her alanda kendini göstermektedir. Çevreyle sıkı biri bağı olan turizm sektörü için yeşil uygulamalar daha da önemlidir. Konaklama işletmelerinin uyguladıkları yeşil uygulamalar işletmeye hem tasarruf sağlamakta hem de rekabet gücünü arttırmaktadır. Türkiye'de yeşil otelcilik uygulamalarının son yılarda yaygınlaştığı göz önüne alındığında çalışmanın literatüre ve konaklama işletmelerine katkı sağlayacağı düşünülmektedir.

\section{YEŞİL PAZARLAMA KAVRAMI VE GELISŞİMi}

Sosyal pazarlamanın gündeme geldiği 1970'lerden başlayarak pazarlama anlayışının kapsamı değişmiş ve gelişmiştir. 1990'l l yıllardan itibaren çevre konuları önem kazanmış olup tüketicilerin bu konuya olan ilgisi artmıştır (Bradley, 2007; Çabuk, Nakıpoğlu ve Keleş, 2008, Kaya, 2009). 2000'li yıllarda ise çevre bilinci, bilinirliği ve duyarlılığı gelişmiştir. Çevresel problemlerde ki artışın bu konudaki duyarlılığı artırmasıyla birlikte doğal kaynakların kullanımını en aza indirecek temiz teknoloji uygulamaların ise artıracak stratejilerle ilgili ulusal ve uluslararası kurallar, yönetmelikler hızla çoğalmıştır (Giraldo ve Castro, 2014). Çevresel konulara ve özellikle 


\section{Ayşe Nevin SERT}

küresel iklim değişikliğine artan duyarlılık ile beraber pazarlama anlayışına 'çevre odaklılık' kavramı girmiştir. Bu kavramla birlikte yeşil uygulamalar ve yeşil pazarlama anlayışı ortaya çıkarmıştır.

Yeşil pazarlama ilk kez 1975 yılında Amerikan Pazarlama Birliğinin düzenlemiş olduğu 'ekolojik pazarlama' konulu seminerde gündeme gelmiş ve tanımlanmıştır. $\mathrm{Bu}$ tanıma göre; yeşil pazarlama, pazarlama faaliyetlerinin çevre kirliliği, enerji tüketimi ve diğer kaynakların tüketimi üzerindeki olumlu ve olumsuz etkileriyle ilgili çalışmadır (Polonsky, 1994). Peattie (2001), yeşil pazarlama kavramını var olan ürünlerin ve üretim sisteminin negatif sosyal ve çevresel etkisini azaltarak daha az zarar veren ürün ve hizmetleri ortaya koymak olarak tanımlamış olup ürünün ve üretim aşamasının çevreye duyalı olmasına vurgu yapmıştır. İşletmelerin sınırlı doğal kaynaklara sahip olmaları nedeniyle sınırsız istekleri tatmin etme konusunda alternatif yöntemler ve yollar geliştirmek zorunda olduklarına vurgu yapan Polonsky (1994) ise, yeşil pazarlamayı, kişisel ve endüstriyel istekleri tatmin edip, işletmenin hedeflerine ulaşmasını sağlayan pazarlama faaliyetlerinde bu sınırlı kaynakların nasıl kullanacağının dikkate alınmasını sağlayan bir yöntem olarak tanımlamaktadır. En genel tanımıyla yeşil pazarlama, sosyal pazarlama kavramının bir parçası olup ürün, fiyat, tutundurma ve dağıtım gibi pazarlama faaliyetlerinin, müşteri ihtiyaçlarını karşılarken ve işletmelerin amaçlarını gerçekleştirirken doğal çevreye olan olumsuz etkilerin en aza indirilmesini sağlayan bir yoldur (Chamorro ve Banegil, 2005; Bridges ve Wilhelm, 2008; Uydacı, 2011:130; Akdeniz Ar, 2011:56; Varinli, 2012: 33).

Tanımlardan da yararlanılarak yeşil pazarlamanın amaçlarını şöyle sıralanabilir. Yeşil pazarlamanın amacı yeni tüketim alanları oluşturmak değil, sınırlı doğal kaynakları en iyi şekilde kullanmaktır. Yeşil pazarlamanın diğer bir amacı da, çevresel tahribatın önüne geçecek ve sanayinin yol açtığı çevre kirliliğini azaltacak alternatifler aramaktadır. Çevre dostu ürünlerin kullanımını teşvik etmeye, paketleme işlemini en aza indirmeye ve toplumda geri dönüşüm bilincini oluşturmayı hedefleyen yeşil pazarlama tüm bunları gerçekleştirebilmek için sorumluluğu dağıtmayı, tüketicileri, devleti ve gönüllü kuruluşları harekete geçirip işbirliğine yöneltmeyi önemsemektedir (Uydac1, 2011:132).

Yeşil pazarlama uygulamaları zaman içinde değişmiş ve gelişmiştir. Ticaret, toplum ve fiziksel çevre arasındaki etkileşimin daha iyi anlaşılmasına bağlı olarak pazarlamayla ilgili "yeşil" uygulama ve prensipler de zaman içinde gelişmiştir. Bu gelişme "Ekolojik" Yeşil Pazarlama, "Çevreci" Yeşil Pazarlama ve "Sürdürülebilir" Yeşil Pazarlama olarak adlandırılan üç aşamada incelenebilir (Peattie, 1999, 2000):

İlk Evre (1960'lar ve 1970'lerin başı) “Ekolojik" Yeşil Pazarlama: Ekolojik yeşil pazarlama; hem çevresel sorunların oluşmasına etki eden hem de çözümüne katkıda bulunan bütün pazarlama faaliyetleri olarak tanımlanabilir. Bu dönemde çevresel sorunlara odaklanılmıştır. Hava kirliliği, petrol rezervlerinin azalması, petrol sızıntıları, sentetik böcek ilaçlarının ekolojik etkileri gibi çevresel problemler gündemdeydi. İşletmeler kendilerini çevreyle ilgili mevzuata uymakla yükümlü görmekteydiler. Söz konusu mevzuat ise kapsamlı değildi. Bu dönemde birçok önemli işletme bile çevreyle ilgili konuları önlerindeki bir engel olarak algılamaktaydı. Bazı işletmeler ise, müşteri ihtiyaçları ve pazar baskıları doğrultusunda hareket etmeyi öngören klasik pazarlama geleneği yerine, girişimciliği ve değer odaklı olmayı benimsemişlerdi.

İkinci Evre (1980'1er-90'ların başı) “Çevreci" Yeşil Pazarlama: Bu dönemde yaşanan çevresel felaketler (1984'de Bhopla felaketi, 1986'da Çernobil faciası gibi) çevrenin ve insanoğlunun ne kadar korunmasız olduğunu göstermiştir. Bu felaketler çevre bilincini geliştirmiş ve "Temiz Teknoloji", "Yeşil Tüketici", "Eko-performans", "Rekabet Avantajı", "Çevresel Kalite", "Sürdürülebilirlik" gibi kavramlar ortaya çıkmıştır. Bugünün ihtiyaçlarını, gelecek nesilleri tehlikeye atmadan karşılamak olarak özetlenebilecek sürdürülebilirlik kavramı da bu dönemde 
1987'de "Brundthland Raporu" nda yer almıştır. Yeşil pazarlama çevresel etkileri çok belirgin olan endüstrilerde ve ürünlerde yoğunlaşmıştır (petrol, madencilik, araba gibi). Ancak ikinci evrede sürdürülebilirlik kaygısı çevresel konuların içeriğini genişletmiştir. Eko sistemin ve habitatların zarar görmesi, canlı türlerinin kaybı, gelişmekte olan ülkelerdeki yoksulluk gibi konular da gündeme gelmiştir. Çevresel pazarlama evde kullanılan araç gereçlerden (halı, beyaz eşya, temizlik maddeleri vb.) turizm ve bankacılık gibi hizmet sektörü de dahil her türlü mal ve hizmetleri içine almıştır. Bu dönemde yeşil uygulamaların kapsamı ve uygulama alanı genişlerken, işletmeye getirdiği yük de tartışma konusu olmuştur.

Üçüncü Evre (2000’lerin başından günümüze) "Sürdürülebilir" Yeşil Pazarlama: Sürdürülebilir pazarlama, yeşil pazarlama ve çevresel pazarlamayı içine alacak şekilde, sadece ürünü kapsayan yeşil hareketlerden değil, tüm yönetim ve pazarlama süreçlerindeki kalkınmayı ve bunu kültürel bir yaşam tarzı olarak topluma sunmayı amaçlayan pazarlama biçimini ifade eder. Pazarlama yeşil pazarlamayla daha sıkı bir şekilde ilişkilendirilmektedir. Birçok endüstride, kirlenmeyi azaltmak ve kaynakları korumak için teknolojiler ve üretim sistemleri geliştirilmiştir. Amaç, sadece çevreye yapılan zararları en aza indirmek değil aynı zamanda sürdürülebilirliği gerçekleştirmektir. Sürdürülebilir pazarlama yönetimi ile işletmelerin; çalışanlarından ve çevresinden itibar elde edeceği, işletmecilik aktivitelerinde etkinlik sağlayacağı, marka değerini yükselteceği, reklâm maliyetlerini düşüreceği, yenilikçi bir işletme yapısına ve düşük finansman maliyetlerine sahip olacağı ve daha az enerji sarfiyatı gerçekleştireceği varsayılmıştır.

Grant (2008), yeşil, daha yeşil ve en yeşil olmak üzere yeşil pazarlama anlayışını üç evrede ele almıştır. "Yeşil" ürün ve diğer süreçlerde doğa dostu yeni standartlar getirmektedir. İşletmelerin kurumsal olarak kendilerini tüketicilere anlatmaları önem kazanmıştır. Bilinçli tüketiciler sadece ürünün özelliklerine değil işletmelerin tüm işleyişine de dikkat etmektedirler. Bu nedenle işletmelerin yeni standartlar belirlediklerini göstermeleri gerekmektedir. Daha Yeşil; sorumluluğu tüketiciler ile paylaşmaktır. Tüketicileri yeşil davranışlar içine sokmak, onları hizmeti veya ürünü nasıl daha çevre dostu kullanabilecekleri hakkında eğitmeyi hedefler. "En Yeşil" ise yeni iş modelleri gibi yenilikçilik süreçlerini desteklemek" olarak tanımlanabilir. Şirketlerin üretim süreçlerinden ürünlerini tüketicilere sunma şekillerine kadar her aşamada büyük değişikler yapmasını amaçlamaktadır.

Yeşil pazarlama ile geleneksel pazarlama karşılaştırılarak yeşil pazarlamanın daha iyi anlaşılması mümkündür. Tablo 1'de yeşil pazarlamayla geleneksel pazarlama karşılaştırıldığında aralarında önemli farklılıklar olduğu görülmektedir. Yeşil pazarlamanın kar amacı güderken çevreyi de göz ardı etmediği görülebilmektedir. Devlet bir paydaş olarak algılanır, talepler maliyeti düşük olan ürüne yönlendirilir. Geleneksel pazarlama da ise müşteri ihtiyaçları ve kar amacı önemli olup devlet düzenleyici ve sinırlayıcı olarak görülmekte, talep ise karı en yüksek olan ürüne yönlendirilmektedir (Miles ve Russell, 1997).

Geleneksel pazarlamayla olan farklılığın ortaya konulduğu yeşil pazarlama uygulanmasının işletmelere sağladığı bazı faydalar vardır (Levinson ve Horowitz, 2011:162; Nemli, 1998): İlk olarak, yeşil ürünlerin ve hizmetlerin pazarlaması çok daha kolaydır. İkinci olarak premium fiyat üzerinden pazarlanmaları mümkün olduğu için karlıdır. Üçüncü olarak, yeşil ürün ve hizmetler çevre dostudur: Daha az kaynak, daha az enerji, daha çok organik ve doğal malzeme kullanırlar; dolayısıyla daha az kirlenmeye neden olurlar, daha düşük seviyede karbon salarlar (küresel ısınmaya sebep olmazlar) ve atılımları daha kolay olur. Dördüncü olarak düşünülenin aksine, doğru tasarlandığında üretim daha ucuza mal olur. Beşinci olarak, işletmenin çevre dostu olması halkla ilişkileri ve imajı açısından önemli olup işletmenin sosyal sorumluluğa verdiği önem vurgular. Altıncı olarak ise, işletmelerin çevre dostu olmaları yasalara karşı daha güvencede olmalarını sağlamaktadır. 
Ayşe Nevin SERT

Tablo 1: Geleneksel ve Yeşil Pazarlama Arasındaki Farklar

\begin{tabular}{|l|l|l|}
\hline Amaçlar/Perspektif & \multicolumn{1}{|c|}{ Yeşil Pazarlama } & \multicolumn{1}{|c|}{ Geleneksel Pazarlama } \\
\hline Amaç & $\begin{array}{l}\text { Müşteri gereksinmelerini, kar } \\
\text { amacı güderek ancak çevresel } \\
\text { olarak sürdürülebilir yoldan } \\
\text { karşlamak. }\end{array}$ & $\begin{array}{l}\text { Müşteri gereksinmelerini kar } \\
\text { amacı güderek karşllamak. }\end{array}$ \\
\hline Müşteri Perspektifi & $\begin{array}{l}\text { Ürünü satın alan ve dişarıda } \\
\text { kalan mağdurlar ya da tüm } \\
\text { paydaşlar }\end{array}$ & Var olma nedeni \\
\hline Devlet Perspektifi & $\begin{array}{l}\text { Sürdürülebilir bir ekonominin } \\
\text { oluşturulmasında ve } \\
\text { yönetilmesinde paydaş. }\end{array}$ & $\begin{array}{l}\text { Düzenleyici ve sinırlayıcı. İdare } \\
\text { edilmelidir. }\end{array}$ \\
\hline Talep Perspektifi & $\begin{array}{l}\text { Talepleri, düşük maliyetli } \\
\text { ürünlere yönlendirmek. }\end{array}$ & $\begin{array}{l}\text { Bütün ürünlere eşit mesafede } \\
\text { durmak. Karı en yüksek olan } \\
\text { ürünlerde yoğunlaşmak. }\end{array}$ \\
\hline
\end{tabular}

Kaynak: Miles ve Russell, 1997:154.

$\mathrm{Bu}$ faydalarının yanında yeşil pazarlama uygulamaları uzun vadede işletmelerin giderlerini azaltarak karlılığını artırmaktadır. İşletmeler yeşil pazarlamayı amaçlarına ulaşmada kullanabilecekleri bir fırsat olarak gördükleri gibi daha fazla sosyal sorumluluk sahibi olma konusunda ahlaki bir yükümlülük içerdiğini düşünmektedirler. Atık tasfiye maliyeti veya malzeme kullanımındaki azalma da işletmeleri yeşil pazarlamaya yönlendiren önemli bir etkendir (Polonsky, 1994). Ayrıca tüketicilerin, rekabetin, çevreci örgütlerin ve devletin baskısı da işletmelerin bu uygulamalara yönelmelerinde etkili olduğu görülmektedir. Tüketici isteklerinin ve duyarlılıklarının değişmesiyle birlikte işletmeler bu isteklere cevap vermek için değişiklik yapmak zorunda kalmaktadırlar (Grant, 2008). Örneğin Kuzey Kutbunda yaptığ petrol arama çalışmalarıyla çevreye zarar vereceği düşünülen Shell firmasına bu çalışmasında destek veren LEGO firması, Greenpeace'in başlattığı kampanyaya 3 ayda 1 milyondan fazla kişinin katılması nedeniyle bu desteğini çekeceğini açıklamak zorunda kalmıştır (Greenpeace.org, 2014). Rakiplerin çevre faaliyetleri, işletmelerin yeşil pazarlamaya önem vermelerine neden olmaktadır. İşletmeler rakiplerinin çevreci davranışlarını iyileştirdiklerini gözlemleyip aynı davranışı göstermeye, yeşil pazarlama uygulamalarıyla farklılık yaratıp tüketicilerinin kararlarında etkin olmaya çalışırlar (Grant, 2008). Örneğin, Greenpeace “Modayı Detoksla" kampanyası başlatmıştır. Bu kampanya çerçevesinde birbirlerine bakarak kampanyaya katılan Nike, Adidas, Puma, H\&M, M\&S, C\&A gibi markalar ürünlerinde kullandıkları zararlı maddeleri azaltmaya başlamışlardır (Greenpeace, 2012). Çevreci örgütlerin baskısı işletmeleri yeşil pazarlamaya yönlendiren diğer bir etkendir. Çevre gönüllü kuruluşları, günümüzde baskı grupları kategorisinde çok etkin bir yer tutmaktadır (Uydacı, 2011). Devletin yaptığı bazı uygulamalar işletmeleri daha sorumlu davranmaya zorlayarak yeşil pazarlamayı desteklemektedir. Devlet, işletmeler üzerinde politik ve ekonomik baskılar oluşturan en önemli paydaşlardan biridir. Devletin izlediği politikalar, ambalaj içeriği, ürünün oluşturulması, dağıtım kanalları gibi konularda olacağı gibi diğer yönlerden de işletme stratejilerini etkilemekte olup işletmeleri genel anlamda çevreye duyarlı hareket etmeye zorlayan yasalar çıkartmaktır (Banerjee, Easwar ve Rajiv, 2003). 


\section{Yeşil Pazarlama Karması}

Pazarlama faaliyetlerinin yürütülmesi esnasında bir pazarlama yöneticisinin üzerinde karar vermek zorunda olduğu temel değişkenlere pazarlama bileşenleri veya pazarlama karması adı verilmektedir (Kotler, Armstrong, Sounders ve Wong, 1999). İşletmeler, yeşil pazarlama hedeflerine ulaşabilmeleri için tüm pazarlama bileşenlerini bu doğrultuda yapılandırmaları gerektiği görülmektedir (Bradley, 2014).

Tablo 2: Geleneksel Pazarlama ile Yeşil Pazarlama Karması Elemanlarının Karşılaştırılması

\begin{tabular}{|c|c|c|}
\hline $\begin{array}{l}\text { PAZARLAMA } \\
\text { KARMASI } \\
\text { ELEMANLARI }\end{array}$ & YESİL PAZARLAMA & GELENEKSEL PAZARLAMA \\
\hline ÜRÜN & $\begin{array}{l}\text { Ürünün çevresel dizaynı; Uzun süreli } \\
\text { kullanıma uygun, verimli enerji } \\
\text { kullanımı, etkin geri dönüşümü olan, } \\
\text { yaşam döngüsü sorumluluğu, üretim } \\
\text { ve tüketim maliyetini dikkate alma. }\end{array}$ & $\begin{array}{l}\text { Planlı eskime, kısa ömürlü } \\
\text { ürünlerin dizayn edilmesi, tek } \\
\text { kullanımlı ürünler, üretim veya } \\
\text { tüketim maliyetlerine önem } \\
\text { vermemek. }\end{array}$ \\
\hline $\begin{array}{l}\text { KİTLE } \\
\text { İLETIŞIMIMI }\end{array}$ & $\begin{array}{l}\text { Çevresel etiketleme. Akılcı tüketime } \\
\text { yönelmek. }\end{array}$ & $\begin{array}{l}\text { Medyayı kullanarak hem birincil } \\
\text { hem de seçilmiş talepleri } \\
\text { harekete geçirmek. }\end{array}$ \\
\hline DAĞITIM & $\begin{array}{l}\text { Yaşam döngüsü ve dağıtım toplam } \\
\text { maliyeti dikkate alınır. }\end{array}$ & $\begin{array}{l}\text { Dağıtım, dağıtım maliyeti ve } \\
\text { stratejik hedefler arasındaki } \\
\text { ilişkiye göre şekillenir. }\end{array}$ \\
\hline $\begin{array}{l}\text { KİŞISISEL } \\
\text { ILETIŞŞIM }\end{array}$ & $\begin{array}{l}\text { Tüketici ihtiyaçlarını çevreye en düşük } \\
\text { maliyetle karşılamaya ve uzun vadeli } \\
\text { kar elde etmeye odaklanır. }\end{array}$ & $\begin{array}{l}\text { Tüketici ihtiyaçlarını kar elde } \\
\text { etmek için karşılama odaklanır. } \\
\text { İhtiyaç olmayan ürünlere talep } \\
\text { oluşturmaya çalışmak. }\end{array}$ \\
\hline IUTUNDURMA & $\begin{array}{l}\text { Eko etiketleme, rasyonel tüketime } \\
\text { yönlenme, uzun dönemli karlıllğı } \\
\text { hedefleyerek çevreye en az vererek } \\
\text { müşteri ihtiyaçlarını karşılamak. }\end{array}$ & $\begin{array}{l}\text { Kitle iletişim araçları kullanılarak } \\
\text { talep yaratmak. Ürünlerin } \\
\text { görselliğini, çekiciliğini ön plana } \\
\text { çıarmak. Az giden ürünler için } \\
\text { talep yaratmak. Müşteri } \\
\text { ihtiyaçlarını sadece karlılık } \\
\text { düşünülerek karşılamak. }\end{array}$ \\
\hline FIYAT & $\begin{array}{l}\text { Toplam maliyet değerlendirmesi, } \\
\text { toplam maliyet muhasebesi ya da } \\
\text { stratejik amaçları ve talepleri ve } \\
\text { maliyeti dikkate alarak fiyat } \\
\text { belirlemek. }\end{array}$ & $\begin{array}{l}\text { Pazarlama amaçları, mali } \\
\text { hedefler ve talep arasındaki ilişki } \\
\text { baz alınarak oluşturulmuş } \\
\text { stratejik karar. }\end{array}$ \\
\hline
\end{tabular}

Kaynak: Miles ve Russell, 1997:155.

Tablo 2'de yeşil pazarlama ve geleneksel pazarlamada pazarlama karması elemanları karşılaştırmalı olarak verilmiştir. Yeşil pazarlamada, ürünün çevreye duyarlı olmasına dikkate edilir. Fiyatın maliyeti göz önüne alarak oluşturulduğu, dağıtımın ise yaşam döngüsünü ön plana 


\section{Ayşe Nevin SERT}

çıkaracak biçimde planlandığı, tutundurmanın ise çevreye en az zarar verecek şekilde şekillendirildiği görülmektedir (Miles ve Russell, 1997; Bradley, 2007).

Yeşil Ürün: Pazarlama karmasında yeşil ürün, dünyayı kirletmeyen, kaynakları daha az tüketen, geri dönüştürülebilen ürünler olarak tanımlanabilir (Uydacı, 2011). Yeşil ürünler genellikle çevre dostu süreçlerden geçerek oluşturulur. Dayanıklı ve daha az toksit olma eğilimindedir; genellikle geri dönüşümlü malzemelerden üretilmektedir. (Davari ve Strutton, 2014). Bir ürünün yeşil olup olmadığına, ürünün tüketicilerin ihtiyaçlarını ve isteklerini tatmin etmesi, enerji ve doğal kaynakların sürekliliğini sağlaması ve koruması, canlılara, insanlara veya diğer canlılara zarar vermemesi, kullanım ve tüketim yoluyla çevreye zarar vermemesi gibi özellikleri incelenerek karar verilebilir (Hussein ve Cankül, 2010). Yeşil ürün geri dönüşümü mümkün olan, tekrar kullanılabilen ya da dönüştürülebilen ürün olmalıdır. Ayrıca yeşil ürün, paketlemede ambalaj malzemelerinin az kullanıldığı, yeniden tüketiminin mümkün olduğu, daha dayanıklı olan, tamir edilebilir, daha yararlı, doğaya ve canlılara zarar vermeyen ürünler olmalıdır (Davari ve Strutton, 2014).

Yeşil Fiyat: Yeşil fiyat, tüketicilerin yeşil ürün almak için ödemek zorunda olduğu fiyattır. Yeşil stratejilerin uygulanması nedeniyle yeşil ürünün maliyeti yüksek olabilir. Tüketicileri, hem kendileri hem gelecek nesiller için hem de çevre için daha fazla ödemeye razı etmek zorunda olduklarından maliyetler daha da artmaktadır (Peattie ve Crane, 2005). Tüketiciler ürünün benzerlerine göre daha çok yarar sağladığını düşündüklerinde fazla ödemeye razı olmaktadırlar. Burada can alıcı nokta farklılaşmadır. Yeşil değerlerin farklılaşması, daha iyi performansın, üstün dizaynın, estetik çekiciliğin, yeni yeşil özelliklerin ve işlevlerin olmasıdır (Mishra ve Sharma, 2012).

Yeşil Dağıtım: Yeşil pazarlama karmasında yeşil dağıtım önemli yer tutmaktadır. Çevrenin korunması için dağıtım politikası ile ilgili olarak alınabilecek tedbirler içerisinde, ürün dağıtımının mümkün olduğunca az yakıt harcanarak yapılmasına olanak tanıacak tedbirlerin alınması, satış noktalarının müşterilerin daha az zaman ve yakıt tüketeceği biçimde yerleştirilmesi, gereksiz zaman, para ve kağıt harcanmaması gerekmektedir (Yüksel, 2002). Şirketler üretim ve dağıtım tesislerini nereye kuracaklarını iyi düşünmelidirler. Çevreciler daha çok bölgesel üretimi gerektiren yerel bazlı üretimleri desteklemektedirler. Yeşil pazarlamayı benimseyen şirketler farklı dağıtım kanalları kullanabilirler (Kotler, 2011).

Yeşil dağıtım söz konusu olduğunda "ters lojistik" kavramı da önem kazanmaktadır. Üretici işletmeler tarafından kullanılmış paketlerin, parçaların ve artık işe yaramayacak ürünlerin kanaldaki aracıların yardımıyla tüketicilerden geri toplanması faaliyetleri önem kazanmaktadır. Buna ters lojistik faaliyetleri de denilebilir. İletmelerin ters lojistik stratejileri ve süreçleri geliştirmede 6R'yi dikkate almaları gerektiğini öne süren Varinli (2012), 6R'yi içeren aşamaları tanımlamıştır.

Tanımlama (Recognition): Ürünlerin ters lojistik sistemine dahil olması için kontrol ve takibi. Geri Alma (Recovery): Ürünlerin yeniden değerlendirmek için toplanması.

- Yeniden Değerlendirme (Review): Malzemelerin yeniden üretime uygunluğunu, ya da parçalarına ayrılarak yok edilmesi gereğini test ederek ortaya çıkarmak.

- Yenileme (Renewal): Ürünün orijinaline göre yeniden üretilmesi veya uygun parçalarının tekrar kullanılmak üzere ayrıştııılması.

- Ayrıştırma (Removal): Yeniden üretime tabi tutulamayan ürünlerin atılması ve yeniden üretilmiş ürünlerin pazarlanmas1.

- Yeniden Üretim (Reengineering): Daha iyi bir tasarımla mevcut ürünlerin geliştirilmesi ve değerlendirilmesi. 
Yeşil Tutundurma: İşletmeler, tutundurma faaliyetlerinde, kamuoyunu, yaptığı yeşil pazarlama uygulamaları konusunda bilgilendirmelidir. $\mathrm{Bu}$ nedenle yeşil pazarlama sürecindeki tutundurma faaliyetlerini kısaca 'yeşil iletişim çabaları' olarak da tanımlanabilir. İşletmenin, çevre-dostu, yeşil ya da sürdürülebilirlik ilkesine sahip olduğunu topluma anlatması ve çeşitli faaliyetler ile toplumu bu konuda bilgilendirerek, yeşil tüketicilik anlayışının benimsenmesine yardımcı olması yeşil tutundurma faaliyetlerinin amacıdır (Dilek, 2012).

Mishra ve Sharma (2012), yeşil tanıtım araçlarının, genellikle, tüketicileri yeşil ürünleri tercih etmekle çevreye faydalı olacaklarına ikna etmek için kullanıldığını belirtmiş ve yeşil tanıtımın bazı kriterlere sahip olması gerektiğini vurgulayarak bu kriterleri sıralamışlardır: 1-ürünle biyofizik çevre arasındaki ilişki ortaya konur 2- ürün/hizmet vurgu yapmadan yeşil yaşam tarzını destekler, onaylar 3- çevreye duyarlı kurumsal imajı sunulur, geliştirilir ve devamı sağlanır. Kotler (2011) ise, yapılan tutundurma çalışmalarının kağıt, mürekkep ve diğer kaynakların kullanımını en aza indirecek şekilde düzenlenmesi gerektiğini, etiketlerin, ürün içerikleri hakkında tüketicilere ayrıntılı bilgi verecek şekilde hazırlanmasının önemli olduğunu ve internet ortamının yeşil tutundurma için daha uygun bir araç olarak kabul edilmesinin doğru olacağını öne sürmüştür.

\section{Otel İşletmelerinde Yeşil Pazarlamanın Önemi}

Bugünkü kuşakların yaşam kalitesini yükseltirken, gelecek kuşaklara aynı şansı verecek bir dünya bırakmak olarak tanımlanabilecek sürdürülebilir kalkınma, son yıllarda çevresel kirlenmenin artmasıyla birlikte önem kazanmıştır. Sürdürülebilirlik, çevreyle sıkı bir ilişki içinde olan turizm sektörü için de önemli bir kavramdır. Turizm sektörünün fiziksel çevreye olan bağımlılığından dolayı bu çevrede oluşacak bir kayıp sektörün ayakta kalmasını ve güvenliğini tehlikeye düşürecektir. Turizmin çevresel etkilerinde önemli bir yer tutan otel işletmelerinin plansız, kontrolsüz büyümesi ve işletilmesi ciddi çevresel sorunlara yol açabilmektedir (Dief ve Font, 2010). Punitha ve Rasdi (2013)'ye göre oteller hizmet sektöründeki işletmelerle karşılaştırıldığında daha fazla enerji ve su harcamaktadırlar ayrıca kullanılan dayanıksız tüketim malları çevreye zarar vermektedir. Bununla birlikte, çevresel etkileri azaltacak uygulamalarla tasarruf sağlamak ve müşteri tatminini yükseltmek göreceli olarak daha kolay olduğundan, oteller turizm sektöründe sürdürülebilir uygulamalarıyla dikkat çekmektedir (Dief ve Font, 2010).

Yapılan çalışmalarda yeşil otelcilik olarak adlandırılan otel yönetimi uygulamaları, hem konaklama işletmelerinin enerji ve su tasarrufu sağlamasına hem de doğaya bırakılan atıkların azaltılmasına yardımcı olmaktadır. Rekabetin yüksek olduğu bir pazarda faaliyet gösteren konaklama işletmelerinin mali tasarrufa önem vermeleri gerekmektedir. Enerji, su ve atık imhası için büyük paralar harcayan konaklama işletmeleri sürdürülebilir uygulamalara geçerek işletme performanslarını düşürmeden kaynak kullanımlarını $\% 20$ ile \%40 arasında azaltabilirler (Bohdanowicz, 2005; Mensah, 2006; Kasim, 2007; Richard ve Kelli, 2008, Graci 2012, Punitha ve Rasdi, 2013).

Yeşil otel işletmeciliği sektörde önemi artan bir uygulama olarak görülmektedir. Rekabet baskısı, tüketici ve sivil toplum kuruluşlarının bu konudaki tutumları ve devletlerin çevreyi koruma politikaları yeşil otelciliğe olan ilgiyi artırmaktadır (Atay ve Dilek, 2013). Uluslararası Oteller Çevre Birliği (IHEI) ve Uluslararası otel zinciri Accor'un yaptığı araştırmaya göre otel müşterilerinin $\% 90^{\prime} 1$ yeşil uygulamaları benimseyen ve kullanan otelleri tercih etmektedirler (Mensah, 2006). Ayrıca Kuzey Amerika'da otel müşterilerinin tatmini üzerine yapılan çalışmasının sonucuna göre turistlerin \%75'i kaldıkları otellerin çevre dostu faaliyetlerine katılmak istediklerini belirtmişlerdir (Butler, 2008). Tüketicilerin çevre konularına olan ilgisi 


\section{Ayşe Nevin SERT}

arttıkça yeşil yönetim otellerin rekabet şansını arttırıcı stratejik bir araç haline gelmiştir (Shieh, 2012). Bu ilgi nedeniyle gelecekte çevreye duyarlı oteller popüler olacaktır. Bu otellerin çevreye duyarlılığı kuruluş aşamasında başlayacak daha sonra verilen hizmet ve yapılan çevre uygulamalarıyla doğanın korunmasına önem verilecektir. Böylece otel işletmelerinde maliyetlerde düşüş ve karda artış sağlanabilecektir (Holjevac, 2003). Gonzalez ve Leon (2001) yaptıkları çalışmada otel işletmelerinde çevresel kalitenin oluşmasında önemli rol oynayan enerji, su, katı atık, gürültü ve peyzaj gibi unsurları dikkate almış ve bu unsurların iyi yönetilmesi durumunda fiyat ve talep üzerinde olumlu etkisi olduğunu belirlemişlerdir. Dolayısıyla Butler'e göre (2008) yeşil yönetim, artık, otellerin stratejik ve operasyonel planlarında önemli bir yer tutmaya başlamıştır.

Birçok önemli otel çevreyi koruma programları geliştirmişleridir. Hilton Otelleri, geliştirdikleri bir sistemle "gri su" yu arıtıp bahçe sulamada kullanmaktadır. Hilton kurumsal yönetimi tarafından oluşturulan Çevresel Rapor (HER) sistemiyle bütün tesislerinin çevreyle ilgili faaliyetleri izlenebilmekte ve gerektiğinde müdahale edilebilmektedir. Ayrıca Accor otel zinciri, otellerinin bulunduğu bölgelerde doğal ortamı korumak ve yerel kalkınmayı desteklemek için "Dünya Misafir Programı" oluşturmuştur. Marriott otelleri "Yeşil Marriott" programı ile doğal çevrenin korunması ve yerel halkın katılımını sağlamayı amaçlamıştır. Rezidor Grup "Sorumlu İşletme Programı" üç konu üzerinde yoğunlaşmıştır: Müşteri ve çalışanların sağlığı ve güvenliği, işletmede ve toplumda sosyal ve etnik farklılıklara saygılı olmak ve çevre üzerindeki olumsuz etkileri azaltmak (Dief ve Font, 2010).

\section{Otel İşletmelerinde Çevresel Yeşil Pazarlama Uygulamaları}

Çevresel konuların önem kazanması yeşil otelcilik uygulamalarında su ve enerji kullanımını, geri dönüşüm ve atık yönetimini önemli hale getirmektedir.

Su Kullanımı: Su hayatta olduğu gibi turistik konaklama işletmelerinin de temel girdilerinden birisidir. Gittikçe azalan bir kaynak haline gelen ve pahalılaşan su bütün otellerin temel ihtiyaçlarındandır. Su olmaksızın otel işletmelerinde hizmet üretmek ve sunmak hemen hemen olanaksızdır (Tuna, 2007). Oteller, suyun en fazla kullanıldığı tesislerdir. Çoğu otellerde su tüketimine ödenen bedel toplam masrafın \%15'ni oluşturmaktadır. Otellerdeki toplam suyun \%45- 50 si otel odalarında tüketilmektedir. Su tüketiminin büyük bölümü duş, banyo, yüzme havuzları, çamaşırhaneler, bahçe sulama, spor etkinlikleri ve golf sahalarına gitmektedir. Otel odasında kullanılan suyun \%56'sı duş veya banyoda, \%25'i tuvalette, \%9'u lavaboda ve \%10'u temizlemede kullanılmaktadır. (Öztürk, 2004). Green Lodging Programına göre, otellerde, dolu odaların günlük su kullanımı ortalama 800 litredir. Sadece su tasarruflu armatör kullanan otellerin su faturalarından \% 25 ile \%30 arasında tasarruf sağladıkları görülmüştür (Richard ve Kelli, 2008). Örneğin Kanada'da Holiday Inn otelinde duşlarda ve musluklarda kullanılan bir aparatla 14.852 Kanada doları tasarruf sağlamaktadırlar (Graci, 2002). Su tasarrufu önemli olmakla birlikte tatil yapmak amaciyla otellerde konaklayan turistler su kullanımı konusunda kısıtlamaların olduğu yerlerde konaklamayı istemeyebilirler. $\mathrm{Bu}$ nedenle tüketicilerde tatminsizlik yaratmadan bilgilendirme yaparak kullanım azaltmaya çalışabilir.

Enerji Kullanımı: Yenilenemeyen enerji kaynaklarının sürdürülebilir kullanımıyla ilgili farkındalığın artmasıyla birlikte konaklama işletmelerinde enerji tasarrufu ve alternatif enerji kaynaklarının kullanımı önem kazanmıştır (Cooper, Fletcher, Fyall, Gilbert, ve Wanhill, 2008). Yapılan bir araştırmaya göre dünyada tüketilen enerjinin üçte biri otellerinde dahil olduğu binalarda kullanılmaktadır (Punitha ve Rasdi, 2013). Buna bağlı olarak otellerde uygulanan enerji tasarrufu ve kaynak yönetimiyle daha ileri bir çevresel sürdürülebilirlik hedeflenmektedir (Richard ve Kelli, 2008). Yeşil Enerji Yönetimi; ürün kalitesinden, güvenlikten veya çevresel tüm 
koşullardan fedakarlık etmeksizin ve üretimi azaltmaksızın enerjinin verimli kullanımı doğrultusunda yapılandırılmış ve organize edilmiş disiplinli bir çalışmadır (Watson vd., 2010). Otellerde başarılı bir enerji yönetiminin oluşturulabilmesi için enerji yönetiminin, otelin bütün yönetim sistemiyle entegre olması gerekmektedir. Satın alma, bütçe oluşturulması, kilit personel eğitimi, izleme, denetleme enerji yönetimine dahildir (Deng ve Burnett, 2002).

Otellerde aydınlatma tüm enerji kullanımının \%25'ini oluşturmaktadır. Ampullerin enerji tasarruflu olanlarla değiştirilmesi, hareket sensorlarının yerleştirilmesi, otellerde enerji tasarrufu sağlamaktadır. Pencereler yenilenerek ya da yalıtım yapılarak ısıtma ve soğutma için kullanılan enerji azaltılmaktadır (Richard ve Kelli, 2008). Soğuk iklimlerde isınmak, sıcak iklimlerde soğutma amacıyla enerji kullanımının azaltılması hem otele hem de çevreye fayda sağlamaktadır. Ayrıca ileri teknoloji güneş kontrol sistemleri, işletmelerde enerji tasarrufunda en uygun çözümleri sunmaktadır. Bilgisayar sistemlerinin etkin kullanımıyla, 1sıtma, havalandırma, aydınlatma gibi konularda enerjinin kontrolü mümkün olmaktadır. Bu sayede kullanım söz konusu olmadığında; odalar, koridorlar veya tüm ünitenin otomatik olarak elektriğinin kapanmasına da olanak sağlanmaktadır (Cooper vd., 2008). Örneğin Singapur Grand Hyatt oteli yeşil enerji yönetimini uygulayarak elektrik faturalarından yıllık 1 milyon dolar tasarruf sağlamıştır (Punithal ve Rasdi, 2013). Toronto'da Fairmont Royal York Otel Enerji Koruma programına 25.000-\$ dolar yatırım yaparak 1sıtma sistemindeki kaçakları bulmuş onarmıştır ve böylece 200.000-\$ tasarruf sağlamıştır (Graci, 2002).

Geri Dönüşüm: Çok çeşitli atık malzemelerin (cam, kağıt, alüminyum, plastik, pil, motor yağı, akümülatör, beton, organik atıklar, elektronik atıklar vb.) çeşitli fiziksel ve/veya kimyasal işlemlerle ikincil hammaddeye dönüştürülerek tekrar üretim sürecine dahil edilmesine "geri dönüşüm" denilmektedir (Kozak, 2010). Resepsiyon veya otel yönetim birimlerinde kağıt ürünlerin yeniden kullanımı, şampuan ve banyodaki diğer kişisel temizlik ürünlerinin birkaç kullanımlık kişisel kaplar içinde değil; doldurulabilir ve yeniden kullanılabilir sabit kaplarda sunulması, tüm yiyecek içecek servis gereçlerinin tek kullanımlık değil, dayanıklı ürünlerden seçilmesi, tek kullanımlık ürünlerin kullanılması gerektiğinde ise ürünlerin geri dönüştürülebilir olmalarına dikkat edilmesi gerekmektedir (Güneş, 2011). Bohdanowicz'in (2005), yaptığı çalışamaya göre otellerde oluşan atıkların yaklaşık \% 50-60'i geri dönüşümle tekrar kazanılabilir.

Atık Yönetimi: Atığın kaynağında azaltılması, özelliğine göre ayrılması, toplanması, geçici depolanması, ara depolanması, geri kazanılması, taşınması ve bertaraf işlemleri sonrası kontrolü ve benzeri işlemleri içeren bir yönetim biçimidir (cevreonline.com). Konaklama işletmelerinde, katı ve sıvı atık oluşumunun fazla olması nedeniyle iyi bir atık yönetimi gerektirmektedir. Ortalama bir otelde her bir müşteri için günlük 1 kilogramdan fazla atık oluşmaktadır (Bohdanowicz, 2005). Konaklama işletmelerinin plastik, metal, cam, kağıt ve yiyecek katı atıklarını geri dönüşüm amacıyla ayrıştırılması doğal çevrenin korunması açısından büyük önem taşımaktadır. Geri dönüşüm etkinliğini sağlamak için personelin ve müşterinin katılımı sağlanmalıdır (Güneş, 2011). Atık yönetiminin önemi yapılan çalışmalar da ortaya konulmuştur. 2002'de Radisson SAS otellerde yapılan çalışmaya göre ayrıştırılmayan atık günlük her bir konuk başına 3.1 kilogram iken atık yönetimi uygulayan Scandic Otellerinde bu rakam 0.515 kilograma düşmüştür (Bohdanowicz, 2005).

1960'lardan itibaren gündemde olan ve zaman içinde önemi giderek artan yeşil pazarlama kavramı turizm sektörü ve özellikle de otel işletmeleri için oldukça önemli bir kavramdır. Yeşil pazarlama karmasında ürünün uzun süreli kullanıma uygun, etkin geri dönüşümü olması önem kazanmaktadır. Fiyat karmasında ise fiyatın belirlenmesi toplam maliyet değerlendirmesi ve stratejik amaç ve taleplerin dikkate alarak belirlenmesi esas alınmaktadır. Tutundurma ve dağıtımda da çevreye en az zarar verecek uygulamalar önem kazanmaktadır. Ayrıca otel işletmelerine Kültür ve Turizm Bakanlığı tarafından verilen yeşil yıldızı kazandıran çevreci 


\section{Ayşe Nevin SERT}

uygulamalar çevreyi korunurken maliyetleri de azalmaktadır. Bu nedenle her geçen gün yeşil yıldıza olan talep artmaktadır.

\section{Yeşil Belgelendirme Sistemleri}

Kurumlar uluslararası veya yerel örgütlerin belirlediği çevreci ölçütlere göre değerlendirilir ve çevreye uyumluluklarına göre etiket alırlar. Uluslararası Standardizasyon Örgütü (ISO), 14000 Belgeler Dizisi, bu değerlendirmeyi gerçekleştirecek nitelikte hazırlanmıştır. Amaç tüketicilerin ürünlerin ne kadar çevreci olduğunu görmesini sağlamaktır. Yeşil etiketleme hem tüketicinin gelişen çevre bilincine hitap eder, hem de çevreci tutum için üreticilerin sınırlarını zorlamasını sağlar (Emgin ve Öztürk, 2004). Yeşil etiketleme karşılaştırıldığı diğer ürünlere göre çevreye daha az zararlı olduğu kabul edilen ürünlere verilen bir ödül niteliği taşımaktadır (Alagöz, 2007:5). Yeşil etiketler turist tercihini olumlu etkilediğinden dolayı otel işletmeleri için ayrıca önem taşımaktadır (Punithal ve Mondh Rasdi, 2013). Aşağıda uluslararası yeşil belgelendirme sistemleri kısaca açıklanmaktadır:

ISO 14001; işletmelerin uygulamakta olduğu faaliyetlerin potansiyel çevre etkilerini kontrol altına alabilmesinde gerekli olan yapıyı sağlayan standartlar serisidir. Sorunların yüzeysel nedenleri yerine kaynağına inerek çözümlemeyi amaçlar. İçerik olarak, Çevre Yönetim Sistemi'nin temel ilkeleri, bileşenleri ve bu bileşenlerin ne şekilde geliştirilip uygulanacağının tanımlanmasına yöneliktir (Marangoz, 2003). Çevre yönetim sisteminin en önemli unsuru döngü şeklindeki yapısı ve işletmenin her elemanını/parçasını kapsamasıdır. Etkin ve verimli bir çevre yönetim sistemi, herhangi bir problemi ortaya çıtığı ilk anda tespit edebilme, hatta önceden fark edilebilme yeteneğine sahip olmalıdır. Çevre yönetim sisteminin başka bir önemli özelliği, geleneksel yetki ve sorumluluk ilişkilerinden oluşan fonksiyonel yapıyı aşan bir sistem olmasıdır (Nemli, 2001). ISO 14001, politika, planlama, uygulama, ölçme değerlendirme ve yeniden değerlendirme olmak üzere beş boyuttan oluşmaktadır. ISO 14001 çevre yönetim standardı, ulaşılması gereken sayısal ölçütler ortaya koyan bir sertifika yerin performans ölçütlerini belirleyen bir yönetim metodudur (Alford, 1997).

Yeşil Yıldız: Yeşil Yıldız, Kültür ve Turizm Bakanlığı'nın başlattı̆̆ “Çevreye Duyarlı Konaklama Tesisleri" projesi kapsamında, Bakanlık belgeli konaklama tesislerine, belirlenen kriterlere uymaları koşuluyla verilen mevcut Turizm İşletmesi Belgelerindeki yıldızların yeşil olarak gösterildiği ve plaketlerinin üzerinde çevreye duyarlı tesis ibaresinin yazıldığı bir çevre etiketi (eko-label) uygulamasıdır (Turofed, 2016). Çevreye Duyarlı Konaklama Tesisi (Yeşil Yıldız Simgesi) Belgesi alacak tesislerin, çevrenin korunmasına katkıda bulunurken, aynı zamanda tanıtım ve pazarlamalarında bir ayrıcalık yaratabilecekleri, hizmet kalitelerinden ödün vermeden, işletmelerine ve ülke ekonomisine tasarruf yolu ile katkıda bulunabilecekleri, çevrenin korunmasında üstlenecekleri roller ile yörelerinde örnek tesisler olabilecekleri düşünülmüştür. Bu belgenin amacı çevrenin korunması, çevre bilincinin geliştirilmesi ve turistik konaklama işletmelerinde çevreye duyarlı yapılaşmanın ve işletmecilik özelliklerinin teşvik edilmesi olarak siralanabilir (www.kulturturizm.gov.tr).

Yeşil Yıldız kriterleri formunun ana başlıkları ve bu başlık konularının puanları şöyle belirlenmiştir: a) Genel Yönetim (13 konu üzerinden 72 Puan) b)Eğitim (6 konu üzerinden 17 Puan) c) Tesisin Yatak Odalarındaki Düzenlemeler (23 konu üzerinden 70 Puan) d) Tesisin Çevreye Uyumu, Çevreyi Güzelleştirici Düzenleme ve Etkinlikler (6 konu üzerinden 27 Puan) e) Ekolojik Mimari (8 konu üzerinden 42 Puan) f) Enerji (22 konu üzerinden 178 Puan) g) Su (16 konu üzerinden 57 Puan) h) Deterjanlar, Dezenfektanlar ve Tehlikeli Kimyasal Maddeler (6 konu üzerinden 16 Puan) i) Atıklar (12 konu üzerinden 53 Puan) j) Diğer Hizmetler (10 konu üzerinden 51 puan) (kulturturizm.gov.tr). 


\section{YÖNTEM}

"Yeşil pazarlama" kavramının ele alındığı bu çalışmada veriler, nitel araştırma yöntemlerinden örnek olay incelemesi yoluyla toplanmıştır. Nitel araştırmanın 6 temel özelliği; doğal ortama duyarlı olması, araştırmacıya katılımcı bir rol yüklemesi, bütüncül yaklaşım, algıların ortaya konması, araştırma deseninde esneklik ve tümevarımcı analizdir (Yıldırım ve Şimşek, 2000: 21). Örnek olay yöntemi (Case study), tek bir olayı veya birkaç olayı derinlemesine inceleme demektir. Örnek olay yöntemi, var olan yapılanmayı tüm yönleri ile ortaya koyabilme açısından yoğun odaklanmayı gerektiren bir yöntem olarak önem taşımaktadır (Karasar, 1999). Araştırmada örnek olay yönteminin tercih edilmesinin nedenleri araştırma konusunun kendi yaşam çevresinde incelenmek istenmesi, konu ile ilgili derinlemesine bilgi elde edilmesine olanak sağlaması, araştırma merkezinin kendine özgü özelliklere sahip olması sıralanabilir (Yıldırım ve Şimşek, 2000). Bu çalışmada gözlem, görüşme, mevcut dokümanları ve arşiv kayıtlarını inceleme gibi birden fazla veri toplama yöntemi kullanılmıştır.

\section{Araştırmanın Evren ve Örneklemi}

İki tür evren vardır. Birisi, genel evren ve öteki ise erişilebilir araştırma (çalışma) evrenidir. Genel evren soyut bir kavramdır. Tanımlanması kolay ancak ulaşılması zordur. Araştırma evreni ise ulaşılması mümkün olandır. Bu açıdan somuttur (Karasar 1995:110). Bu araştırmanın evreni Türkiye'de yeşil yıldız uygulaması yapan otelleridir. Örneklemi ise Doğa Residence Oteldir. Araştırma için literatür taraması yapılmıştır. Literatür taramasından sonra, Kültür ve Turizm Bakanlığı'nca yürütülmekte olan çevreye duyarlılık kampanyası kapsamında 2012 yılında "Yeşil Yıldız" belgesini almaya hak kazanan Ankara' daki ilk otel olması ve erişilebilir araştırma evreni olması nedeniyle "Doğa Residence Oteli" in tercih edilmiştir.

\section{Araştırma Verilerinin Toplanması}

Örnek olay çalışmasında bir görüşme yapılmıştır. Bunun için bir görüşme formu hazırlanmıştır. Görüşme formunun amacı araştırılan problemle ilgili tüm boyutların ortaya konulabilmesidir (Yıldırım ve Şimşek, 2000). Görüşmede otelin Satın Alma Müdürü ve Kalite Müdürüyle görüşülmüştür. Araştırma sorularında 6 adet soru otelin genel çevresel uygulamalarına yönelik, 12 adet soru ise "yeşil pazarlamaya" yönelik olarak sorulmuştur. Soruların hazırlanmasında Seyhan'ın (2010) Sürdürülebilir Turizm Kapsamında Konaklama İşletmelerinde Çevreye Duyarlı Uygulamalar ve Yeşil Pazarlama: Örnek Olay Çalışması (Calista Luxury Resort Hotel-Antalya) isimli çalışmasından yararlanılmıştır.

\section{Araştırma Verilerinin Analizi}

Görüşmeden elde edilen veriler betimsel analiz yöntemi kullanılarak analiz edilmiştir. Betimsel analiz, çeşitli veri toplama teknikleri ile elde edilmiş verilerin daha önceden belirlenmiş temalara göre özetlenmesi ve yorumlanmasını içeren bir nitel veri analiz türüdür. Bu analiz türünde araştırmacı görüştüğü ya da gözlemiş olduğu bireylerin görüşlerini çarpıcı bir biçimde yansıtabilmek amacıyla doğrudan alıntılara sık sık yer verebilmektedir. Bu analiz türünde temel amaç elde edilmiş olan bulguların okuyucuya özetlenmiş ve yorumlanmış bir biçimde sunulmasıdır (Yıldırım ve Şimşek, 2000). Araştırmada görüşmeden elde edilen veriler; nitel veri analizinde sıklıkla kullanılması, herhangi bir yazılı metni ya da belgeyi inceleme fırsatı vermesi, 


\section{Ayşe Nevin SERT}

verileri sayısal veya istatistiksel olarak sunma olanağı sağlaması gibi özelliklerinden dolayı betimsel analiz yardımıyla çözümlenmiştir.

\section{Araştırma Yapılan Otel İşletmesine Yönelik Tanımlayıcı Bilgiler}

Doğa Residence Otel Ankara'nın şehir merkezinde yer almaktadır. Otelin toplam oda sayısı 43, yatak sayısı ise 87 adettir. Otel 12 ay açık olup şehir oteldir. Otelin çevre politikası; ISO 14001 Çevre Yönetim Sistem Standardını esas alarak hizmet verdiği turizm sektöründe sürdürülebilir kalkınma çerçevesinde otel proses koşullarının öne sürdüğü çevre boyutlarının çevre ve insan sağlığı üzerinde olabilecek etkilerini en aza indirmek için, gerekli faaliyetleri planlamak ve hayata geçirmektir. Bunun yanı sıra Çevre Kanunu ile ilgili mevzuat ve yönetmelikler çerçevesinde; Çevre Yönetim Sistemi'ni benimsemek ve sistemin devamlılığını sağlamak ve sürekli iyileştirmektir. Ankara'da ilk "Yeşil Yıldız"1 alan oteldir.

\section{BULGULAR}

Doğa Residence Otel ISO 14001 Çevre Yönetimi çalışmaları ve Yeşil Yıldız kapsamında atık ayrıştırma ve geri dönüşüm yönetimiyle ilgili çalışmalar yapmaktadır. Bunlara ilişkin faaliyetler aşağıda sıralanmaktadır:

- Hiçbir atık (evsel ve kontamine atık dışında) atılmayıp ayrıştırılmaktadır. Bu ayrıştırma otelin her bölümünde yapılmaktadır.

- Müşteri odalarında atık ayrıştırma kuralları gereği organik ve inorganik çöplerin ayrıştırılmasını sağlayan çöp kutuları bulunmaktadır.

- Kutu içecek yerine cam içecekler kullanılmaktadır.

- Çöpler çöp poşetlerine konulup çöp odasında biriktirilip haftada iki kez çöp toplayan işletmeye verilmektedir.

- Atık yağlar biriktirilmektedir. Bitkisel atık yağlardan biyodizel üreten işletme Deha biodizel tarafından belli zamanlarda bu yağı almaktadır. 2014 yılında $150 \mathrm{~kg}$. atık yağ verilmiştir. 150 milyon m3 su kirlenmekten kurtulmuştur.

- Piller toplanmaktadir.

- Artan sağlıklı günlük yiyecekler Hayvan Barınaklarına verilmektedir.

\section{Enerji Kullanımı}

Otel işletmelerinde enerji işletme maliyetinin önemli bir bölümünü oluşturmakta olup, enerji tasarrufuyla ilgili yapılan uygulamalarla önemli ölçüde tasarruf sağlanabilmektedir.

Doğa Residence Otel'in enerji tasarrufuyla ilgili yapmış olduğu uygulamalar aşağıda belirtilmiştir:

- Odalar kartlı sisteme sahip olup, enerji tasarruf sistemi kullanmaktadır. Müşteri odada bulunmadığında elektrik sistemi çalışmamaktadır.

- Soğutma ve havalandırma pencerelerin açılması durumunda otomatik olarak kapanmaktadır. Koridorlar, yangın merdivenleri (odalar, lobi ve restoran hariç) bütün alanlarda elektrik sensorludur. 
- Lobi ve salonlardaki spotlar LED'dir.

- Odalarda elektrik tasarruflu ve uzun ömürlü lambalar vardır.

- Otelde camları çift cam olup gerekli yalıtımlar yapılmıştır.

Otelin enerji tasarrufu sağlamak amacıyla yaptığı uygulamalar işletmenin enerji kullanımını ve giderlerini azaltmaktadır.

\section{Su Kullanımı}

Otel işletmeleri için önemli bir girdi olan suyun kullanımı hem tasarruf açısından hem de çevresel etkileri açısından önemlidir.

- Doğa Residence Otel odalarında bilgilendirme kartı bulunmaktadır. Bu kartlarda rezervuarlarda ve musluklarda oluşabilecek sızıntıların resepsiyona bildirilmesi gerektiği, yıkanması istenilen havluların küvete atılması belirtilerek müşteriler su tasarrufu konusunda bilgilendirilmektedir. Kartlarda, 1 kişi 1 günde ortalama 5 dakika suyu kapatmadan tıraş olur ve dişlerini fırçalarsa yılda yaklaşık 20 ton su harcayacağı yazılmaktadır.

- Otelde bulunan odalarındaki tüm musluklara ve duşlara "perlatör" denilen suyun hava karışımlı akmasını sağlayan mekanizma takılmış, bu sayede suyun tasarruflu kullanılması sağlanmaya çalışılmıştır.

- Pisuar ve genel kullanım alanlarında bulunan bataryalar sensorludur.

\section{Çalışanların ve Müşterilerin Bilgilendirilmesi}

Otel temizliği atık ayrıştırması, elektrik-su tasarrufu gibi konularda çalışanlara eğitim verilmektedir. Bu eğitimler ayda bir kez yapılmaktadır. Eğitim sırasında yeni işe girenler var ise onlar ilk eğitimlerini diğer çalışanlardan ayrı almaktadır. Yapılan aylık eğitimlerde bilgi vermenin yanında çalışanlardan yapılan uygulamalarla ilgili geri dönüşler alınıp, değerlendirilmektedir. Eğitimler otel kalite müdürü tarafından verilmektedir. Bununla birlikte müşterileri çevre konusunda bilinçlendirmek amacıyla lobide ve restoranda çevre korunmasıyla ilgili hazırlanmış video gösterilmektedir.

\section{Yeşil Pazarlama Karmasına Yönelik Bulgular}

Otelin uyguladığı yeşil pazarlama karması incelenmiştir. Yeşil pazar karmasıyla ilgili otelin yapmış olduğu uygulamalarla ilgili açıklamalar aşağıda verilmektedir:

Yeşil Ürün: Doğa Residence Otel inşaatı aşamasından başlayarak yeşil olarak yapılandırılmıştır. Otelde atıkların azaltılması, geri dönüşümü ve yeniden kullanımı sağlanmaktadır. Su ve enerji tasarrufu sağlanmaktadır. Çalışanların çevre konusunda eğitilmesinin yanında müşteriler de bilgilendirilmektedir. Otel, tarafsız bir kurum olan Kültür ve Turizm Bakanlığı'ndan "Yeşil Yıldız" ödülünü alarak sektörde imajına değer katmıştır. Otelin "Yeşil Ürün" kimliğiyle tam olarak uyuşmayan uygulaması, otelde sunulan yiyeceklerin tamamının organik olmadığıdır. Ancak tüm yiyecek ve içeceklerin organik olarak elde edilmesi oldukça zordur.

Yeşil Fiyat: Araştırma sırasında otelle yapılan görüşmede acentelerle yapılan sözleşmeler ve fiyatlar gizli tutulmuştur. Bu nedenle otel fiyat karşılaştırmasını olanaklı kılan birçok 


\section{Ayşe Nevin SERT}

rezervasyon ağlarına sahip (booking, Expedia, hotel reservation service v.b) Trivago'dan Doğa Residence Otel'in fiyatları hakkında değerlendirme yapılmıştır. Trivago sitesinde Ankara dört yıldızlı 42 şehir oteli bulunmaktadır. Doğa Residence Otel ile aynı konumda olan 42 otel arasında fiyat karşılaştırması yapılmıştır. Ocak 2015 tarihi itibariyle Doğa Residance Otel, 42 otel arasında fiyatlar en düşükten en yükseğe sıralandığında en düşük fiyatlı 7. otel olmaktadır. Yeşil otel olması özelliği fiyatta herhangi bir değişikliğe yol açmamış gibi görünmektedir.

Yeşil Dağıtım: Seyahat acenteleri ve bireysel olarak yapılan rezervasyonlar aracılı̆̆ıyla otele müşteri gelmektedir. Otelin çalışmakta olduğu seyahat acentelerini seçerken yeşil uygulamaları dikkate almadığı anlaşılmıştır. Otel kendi web sitesinden rezervasyon kabul etmektedir.

Yeşil Tüketici: Doğa Residence Oteli müşteri memnuniyetini ve müşterilerin otelin uyguladığı çevreci faaliyetlerle ilgili tutumlarını ölçmek amacıyla anket uygulamaktadır. 9 sorudan oluşan ankette ilk 5 soru müşteri memnuniyetine yönelik, 4 soru ise otelin çevre faaliyetlerine ilişkin sorulardır. Geçerli anket sayısı güvenilir bir örneklem grubu oluşturmak için yetersiz olduğundan müşterilerin memnuniyet düzeylerini ve otelin çevreci faaliyetleriyle ilgili tutumlarını ölçmek mümkün olmamaktadır. Araştırma kapsamında satış sorumlusuyla yapılan görüşmede otelin çevreye duyarlı olması ve bu konuda sahip olduğu plaketlerin müşterilerin tercihlerini etkileyip etkilemediği sorulmuştur. Verilen bilgiye göre müşterilerin genellikle ilk gelişlerinde bu konuyla ilgili bilgilerinin olmadığı ancak konaklama süreleri boyunca oteldeki çevreci uygulamaların dikkatlerini çekmesi sonucunda otele tekrar gelmelerinde etkili olduğu anlaşılmıştır. Satış sorumlusu bu bilgileri konaklama süresince müşterilerden edinildiğini belirtmiştir.

Yeşil Tutundurma: Araştırmada pazarlama ve tutundurma faaliyetlerinde önemli yeri olan otelin web ve facebook sayfaları incelenmiştir. Doğa Residence Otel facebook sayfasından çevreyle ilgili bilgi ve duyurulara ulaşılabilmektedir. Bu sayfada otelin yapmış olduğu çevre etkinliklerine de yer verilmektedir. Facebook sayfası 12 Ocak 2015 tarihi itibariyle 644 beğenme almıştır. Giriş kapısındaki yer alan Kültür ve Turizm Bakanlığının verdiği "Çevreye Duyarlı Tesis" levhası ile otelin müşterileriyle yeşil iletişimi başlamış oluyor. Lobide bulunan çeşitli çevreci plaketler ve odalardaki çevreci uyarılarla bu iletişim devam etmektedir. Ayrıca otelin yeşil yıldız sahibi olması tanınırlı̆̆ını arttırmıştır. Birçok internet sitesinde "çevre dostu otel" olarak ismi geçmektedir.

Yeşil Tedarikçi: Doğa Residence Otel satın alınan ürünlerin ISO ve TSE belgeli olmasına dikkat etmektedir. Gıda ürünlerinde "Tarım ve Köy /İleri Bakanlığı" ve "Sağlık Bakanlığı" onaylı ürünlerin satın alınmasına dikkat edilmektedir. Ancak organik ürünler sağlayan tedarikçilerle çalışmak maliyet nedeniyle zor olduğundan otelde organik ürünlerin sağlanması her zaman mümkün olmamaktadır.

Otel, ürün, fiyat, dağıtım ve tutundurma gibi pazarlama faaliyetlerinde yeşil uygulamalara dikkat ettiği görülmüştür. Otel, atıklarının azaltılması, geri dönüşümü ve yeniden kullanılmasına dikkat etmektedir. Çalışanların bu konuda eğitildiği görülmektedir. Tutundurma çalışmalarında daha çok internet kullanılmaktadır. Tedarikçilerinin ISO ve TSE belgesine sahip ürünleri sağladığına dikkat edilmektedir. Bu uygulamaların müşteriler üzerinde olumlu etki bıraktığı belirtilmiştir.

\section{TARTIŞMA, SONUÇ VE ÖNERİLER}

Son yıllarda, çevre bilinci ve çevrenin korunmasına verilen önem artmıştır. Turizm sektörü için çevrenin korunması sektörün yapısı gereği daha da önemlidir. Sektörün çevreye bağımlı olmasından dolayı çevrede oluşacak herhangi bir tahribatın sektörün varlığını ve güvenliğini 
tehlikeye sokması anlamına gelmektedir. Bu tehlike karşısında yeşil pazarlama ve sürdürülebilir kalkınma turizmin kaynağı olan çevrenin korunmasında öne çıkmaktadır.

Yeşil pazarlama uygulamalarının hem çevreye hem de işletmelere olumlu etkileri vardır. Turizm sektöründeki diğer işletmelere ve oluşumlara göre, otellerin, yeşil pazarlama uygulamalarıyla maliyeti düşürüp müşteri memnuniyetini artırırken çevreye verilen olumsuz etkileri en aza indirmeleri daha kolay gözükmektedir. Otel işletmelerinde yeşil pazarlama uygulamaları (enerji ve su tasarrufu, atık yönetimi) oteller açısından oldukça avantaj sağlamakta, maliyetleri düşürmektedir. Yeşil pazarlamanın otel işletmelerinde uygulanabilmesi ve başarılı olabilmesi için yöneticilerin istekli olması ve çalışanların uygulamalar konusunda eğitilmeleri gereklidir.

Bu çalışmada örnek olay yöntemine konu olan "Doğa Residence Otel", proje aşamasından itibaren uyguladığı çevreci uygulamalar ile "Çevreye duyarlı tesis" özelliğini kazanmış, yeşil yıldız sahibi olmuştur. Otel enerji tasarrufuna yönelik önlemler almıştır. Bu önemlerle enerjide tasarruf sağlanmıştır. Su kullanımı konusunda da tasarruf sağlanmıştır. Otel geri dönüşüm uygulamalarına çok önem vermektedir. Mutfakta, odalarda ve genel kullanım alanlarında atıklar titizlikle ayrıştırılmaktadır. Doğa Residence Otel uygulamalar konusunda müşterilerini bilgilendirip, bu uygulamalardan yüksek verim alabilmek için onları işbirliğine davet etmektedir. Otelin uyguladığı çevreci uygulamaların müşterilerin tercihlerini etkileyen birinci neden olmadığı yapılan görüşmede belirlenmiştir. Bununla birlikte bu uygulamalar otelin maliyetlerini azaltmıştır. Maliyetin azalması yanında otelin tanınırlığına katkıda bulunmuştur. Yeşil pazarlama uygulamalarının her geçen gün önem kazanmasından dolayı otel geleceğe yatırım yapmaktadır. Otelin yeşil uygulamaları fiyatı etkilememiştir. Otelin fiyat seviyesi benzer otellerin fiyatına yakındır. Otel kuruluş aşamasında yapmış olduğu yalıtım, elektrik ve su sistemleriyle yeşil otel uygulamaları için gerekli ilk adımları atmıştır. Ancak otel çalıştığı seyahat acentelerinin yeşil olup olamadıklarına göre seçme şansı olmadığı tespit edilmiştir. Yeşil uygulamaların bütün işletme sisteminde uygulanamadığı görülmüştür.

Otellerin yeşil pazarlama uygulamalarını benimsemeleri işletmelerine büyük katkı sağlamaktadır. Bu uygulamalarla yapılan tasarruf ekonomik kazanç olarak geri dönmektedir. Bu amaçla öncelikle yeni yapılan oteller çevreye duyarlı binalar olarak inşa edilmelidir. Otel müşterileri çevre duyarlılığı konusunda bilinçlendirilmelidir. Böylece seçimlerinde yeşil uygulamaları uygulayan otellere öncelik tanımaları sağlanabilecektir. Ayrıca yeşil oteller çevreye duyarlılıklarıyla imajlarını güçlendirmektedirler. Bu bağlamda konaklama işletmelerinin Kültür ve Turizm Bakanlığı tarafından verilen "Yeşil Yıldız" 1 almaları önemlidir. "Yeşil Yıldız" kriterlerini yerine getirmek için yapılan yeşil uygulama çalışmaları çevreye ve işletmelerine yarar sağlamaktır. Konaklama işletmelerinde turizm faaliyetlerinin çevreye zarar vermeden sürdürülebilir bir anlayışla yürütülmesi hedeflenmelidir.

\section{KAYNAKÇA}

Alagöz, B. S. (2007). Yeşil Pazarlama ve Eko Etiketleme. Akademik Bakış,11, 10.01.2017 tarihinde http://www.akademikbakis.org/sayi11/seldabasarans.htm- sayfasından erişilmiştir.

Alford, S. (1997). A New Management Standard, Canadian Manager, 22(2):13-14.

Akdeniz Ar, A. (2011). Yeşil Pazarlama: Tekstil Sektöründen Örneklerle. İstanbul: Beta Yayıncılık.

Atay, L. ve Dilek, E. (2013). Konaklama İşletmelerinde Yeşil Pazarlama Uygulamaları: İbis Otel Örneği. Süleyman Demirel Üniversitesi İktisadi ve İdari Bilimler Fakültesi Dergisi, 18(1):203219. 


\section{Ayşe Nevin SERT}

Banerjee, S. B, Easwar S. I. and Rajiv K. K. (2003). Corporate Environmentalism: Antecedents and Influence of Industry Type, Journal of Marketing, 67(2):106-122.

Bohdanowicz, P. (2005). European Hoteliers' Environmental Attitudes: Greening the Business, Cornell Hotel and Restaurant Administration Quarterly, 46(2):188-204.

Bradley, N. (2007). The Gren Marketing Mix. 24/11/2014 tarihinde http://www.wmin.ac.uk/marketingresearch/marketing/greenmix.htm, sayfasından ulaşılmıştır.

Bridges, C. and Wilhelm, W. (2008). Going Beyond Green: The "Why and How" of Integrating Sustainability into the Marketing Curriculum. Journal of Marketing Education, 30(1):33-46.

Butler J. (2008). The Compelling “Hard Case” For “Green” Hotel Development. Cornell Hosp Q. 49(3): 234-244.

Chamorro, A. and Banegil, T.M (2006). Green Marketing Philosophy: A Study of Spanish Firms with Ecolabels. Corporate Social Responsibility and Environmental Management,13(1):11-24.

Cooper, C., Fletcher, J., Fyall, A., Gilbert, D. and Wanhill, S. (2008). Tourism Principles and Practice. Fourth Edition, Prentice Hall, Harlow: England.

Çabuk, S., Nakıboğlu, B. ve Keleş, L. (2008). Tüketicilerin Yeşil (Ürün) Satın Alma Davranışlarının Sosyo-Demografik Değişkenler Açısından İncelenmesi. Ç.Ü. Sosyal Bilimler Enstitüsü Dergisi, 17(1): 85-102.

Çevreonline (2017). Atıkların Yönetimi. 03.03.2017 tarihinde http://cevreonline.com/category/atiklar/ sayfasından alınmıştır.

Davari, A. and Strutton, D. (2014). Marketing Mix Strategies for Closing the Gap Between Green Consumers' Proenvironmental Beliefs and Behaviours. Journal of Strategic Marketing, 22(7):1-24

Deng, S. M. and Burnett, J. (2002b). Water use in hotels in Hong Kong. International Journal of Hospitality Management, 21(1):57-66.

Dief, M. and Font, X. (2010). The Determinants of Hotels' Marketing Managers Green Marketing Behaviour. Journal of Sustainable Tourism.18(2):157-174.

Dilek, S.E. (2012). Turizm İşletmelerinde Yeşil Pazarlama Uygulamaları: Bir Alan Araştırması, Yüksek Lisans Tezi, Çanakkale Onsekiz Mart Üniversitesi Sosyal Bilimler Enstitüsü, Çanakkale.

Emgin, Ö. ve Türk, Z. (2004). Yeşil Pazarlama. Mevzuat Dergi, 7(78):11-25.

Ginsberg, J. M. and Bloom, P. N. (2004). Choosing the Right Green Marketing Strategy, MIT Sloan Management Review, 46(1):79-84.

Giraldo, J.M. and Castro, W.A.S (2014). Green Supply Chains: Conceptual Bases and Trends: Applications in Agroindustries. In Alzate, C.A.C and Castro W.A.S (Eds.), Green Supply Chains: Applications in Agroindustries.

Graci, S. (2002). The Greening of Accommodation: A Study of voluntary Environmental Initiatives in the Hotel Industry. Toronto: University of Toronto.

Grant, J. (2008). Yeşil Pazarlama Manifestosu (Çeviri: Nadir Özata, Yasemin Fletcher), İstanbul: MediaCat Kitapları. 
Greenpeace (2012). Haberler. 24.11.2015 tarihinde, http://www.greenpeace.org/turkey/tr/news/lego-shell-anlasmasini-sonlandirdi-91014 /. sayfasından erişilmiştir.

Gonzalez, M. and Leon, CJ. (2001). The Adoption of Environmental Innovations in the Hotel Industry of Gran Canaria. Tourism Economics, 7(2):177-190.

Güneş, G. (2011). Konaklama Sektöründe Çevre Dostu Yönetimin Önemi. KMÜ Sosyal ve Ekonomik Araştırmalar Dergisi, 13(20):45-51.

Güneş, S. (2010). Sürdürülebilir Turizm Kapsamında Konaklama İşletmelerinde Çevreye Duyarlı Uygulamalar ve Yeşil Pazarlama: Örnek Olay Çalışması (Calista Luxury Resort Hotel-Antalya). Yüksek Lisans Tezi, Dokuz Eylül Üniversitesi Sosyal Bilimler Enstitüsü, İzmir.

Holjevac I.A. (2003). A Vision of Tourism and the Hotel Industry in The 21st Century. Hospitality Management, 22(2):129-134.

Hussein, A. ve Cankül, D. (2010). Üniversite Öğrencilerinin Yeşil Pazarlama Faaliyetleri Kapsamında Çevreye İlişkin Davranışlarını Belirlemeye Yönelik Bir Araştırma, Ticaret ve Turizm Ĕ̆itim Fakültesi Dergisi, 1, 50-67.

Karasar, N. (1999). Bilimsel Araştırma Yöntemi, Ankara: Nobel Yayınları.

Kasim, A. (2007) Corporate Environmentalism in the Hotel Sector: Evidence of Drivers and Barriers in Penang, Malaysia. Journal of Sustainable Tourism 15(6):680-699.

Kaya, İ. (2009). Pazarlama Bi' Tanedir. IV. Dijital Baskı, İstanbul.

Kültür ve Turizm Bakanlığı (2017). Yeşil Yıldız Kriterleri 09.04.2017 tarihinde http://tuyup.turizm.gov.tr/Pages/GreenStar.aspx sayfasından erişilmiştir.

Kotler, P. Armstrong, G. Sounders, J. and Wong, V. (1999). Principles of Marketing, Second European Edition, Prentice Hall.

Kotler, P. (2011). Reinventing Marketing to Manage the Environmental Imperative. Journal of Marketing, 75(4):132-135.

Kotler, P. Kartajaya, H. and Setiawa, I. (2014). Pazarlama 3.0. (Çev. Dündar, K.) İstanbul: Optimist Yayınlar.

Kozak, M. (2010). Tekstil Atıkların Yapı Malzemesi Olarak Kullanım Alanlarının Araştırılması. Yapı Teknolojileri Elektronik Dergisi, 6(1):62-70.

Levinson, J.C. and Horowitz, S. (2011). Yeni Pazarlama Kurallar. (Çev. Aksoy, G.) İstanbul: Optimist Yayınlar.

Marangoz, M. (2003). Yeşil Pazarlama ve İşletmelerin Yeşil Pazarlama Anlayış ve Uygulamalarının Değerlendirilmesine Yönelik Bir Araştırma, Basılmamış Doktora Tezi. Dokuz Eylül Üniversitesi Sosyal Bilimler Enstitüsü, İzmir.

Mavi Bayrak (2017). Genel Kriterler, 10.05.2017 tarihinde http://www.mavibayrak.org.tr/tr/icerikDetay.aspx?icerik refno=10 sayfasından erişilmiştir.

Miles, M. P. and Russell G. R. (1997). ISO 14000 Total Quality Environmental Management: The Integration of Environmental Marketing, Total Quality Management, and Corporate Environmental Policy, Journal of Quality Management, 2(1):151-168. 


\section{Ayşe Nevin SERT}

Mensah, I. (2006). Environmental Management Practices Among Hotels in The Greater Accra Region. International Journal of Hospitality Management. 25(3):414-431.

Mishra, P. and Sharma, P. (2012). Green Marketing: Challenges and Opportunities for Business. Journal of Marketing \& Communication, 8(1):35-41.

Nemli, E. (1998). Sürdürülebilir Kalkınma ve İşletmelerin Rolü. Marmara Üniversitesi Sosyal Bilimler Enstitüsü Dergisi. 2(9):292-293.

Nemli, E. (2001). Çevreye Duyarlı Yönetim Anlayışı. Siyasal Bilgiler Fakültesi Dergisi, (23-24):211224.

Öztürk, M. (2004). Otellerde / Motellerde Verimli Su, Aydınlatma Ve Isıtma Enerjisi Kullanımı. 01.12.2016 tarihinde http://www2.cevreorman.gov.tr/belgeler/otel.pdf. sayfasindan erişilmiştir.

Peattie, K. (1999). Trappings Versus Substance in The Greening of Marketing Planning, Journal of Strategic Marketing. 7(2):131-148.

Peattie, K. (2001). Towards Sustainability: The Third Age of Green Marketing. The Marketing Review. 2(2):129-146.

Peatie, K. and Crane, A. (2005). Green Marketing: Legend, Myth, Farce or Prophesy? Qualitative Market Research. An International Journal, 8(4):357-370.

Polonsky, M. J. (1994). An Introduction to Green Marketing. Electronic Green Journal, 1(2):388-412.

Punithal, S. and Mohd Rasdi, R. (2013). Corporate Social Responsibility: Adoption of Green Marketing by Hotel Industry. Asian Social Science, 9(17):79-93.

Richard, M. and Kelli, W. (2008). Hotels \& Resorts. Resorts Worldwide Inc: United States.

Shieh, H. (2012). The Greener, The More Cost Efficient? An Empirical Study of International Tourist Hotels in Taiwan. International Journal of Sustainable Development \& World Ecology. 19(6): 536-545.

Tuna, M. (2007). Turizm, Çevre ve Toplum (Marmaris Örneği), Ankara: Detay Yayıncılık.

Turçev (2017). Ödüllü $\quad$ Tesisler. 08.05 .2017 tarihinde http://www.turcev.org.tr/V2/icerikDetay.aspx?icerik id=31 sayfasından erişilmiştir.

$\begin{array}{lllll}\text { Turofed } & \text { (2016). } & \text { Beyaz } & \text { Yıldiz } & \text { Raporu.18.12.2016 tarihinde }\end{array}$ http://www.turofed.org.tr/Projeler.aspx sayfasından erişilmiştir.

Uydacı, M. (2011). Yeşil Pazarlama. Tekstil Sektöründen Örneklerle, İstanbul: Beta yayıncılık.

Varinli, İ. (2012). Pazarlamada Yeni Yaklaşımlar, Ankara: Detay Yayıncılık.

Yıldırım, A. ve Şimşek, H. (2000). Sosyal Bilimlerde Nitel Araştırma Yöntemleri. Ankara: Seçkin Yayınları.

Yüksel, H. (2002). Üretim Yönetimi Fonksiyonları ile Çevre Yönetim İlkelerinin Bütünleştirilmesi: Çevreye Duyarlı Üretim, Dokuz Eylül Üniversitesi Yayınları, 3 (2):80-97.

Watson, R. Boudreau, M. and Chen, A. (2010). Information Systems and Environmentally Sustainable Development: Energy Informatics and New Directions for The Is Community. MIS Quarterly. 34 (1):23-38.

Tuyup : http://tuyup.turizm.gov.tr/Pages/GreenStar.aspx

Yeşil yıldız tesis sayısı : http://yigm.kulturturizm.gov.tr/TR,9579/turizm-tesisleri.html 